de la transmisión. Y nada más peligroso para la moral burguesa y su indefectible progreso que una radio (o un teatro) para pequeños y pequeñas soberanas de un mundo donde no valen palabras hueras; donde el deseo no capitalizado interviene importunando; donde no se naturaliza el discurso; donde el "yo" no (se) busca (en) el resultado objetivo de una representación. La educación teatral o radiofónica con niños y niñas muestra un principio de acción que no parte de un sujeto soberano, el cual tiembla delante de la comunidad. La desdicha se desentiende del destino; el error hace la educación, creando en la comunidad un espacio de comodidad donde seguir actuando. La mirada a la pedagogía no es la de la peligrosa decepción. No una inmediatez espontánea, sino una espontaneidad inmediata.

“Asunto peliagudo" (118). De la obra no se desprende una respuesta unívoca a los interrogantes planteados sino una sugerente articulación de problemas y propuestas plurales para la educación de identidades no identitarias; "espacios de libertad anclada en el mundo" (194).

\title{
Secrets of Pinar's Game. Court Ladies and Courtly Verse in Fifteenth-Century Spain
}

Roger Boase

Leiden y Boston, Brill, 2017, 2 vols., 916 pp. ISBN: 978-90-04-33835-7

Podrá sorprender a muchas personas — como, de entrada, me sorprendió a mí mismo- que la edición del Juego trobado, obra del poeta Gerónimo Pinar compuesta a fines del siglo XV, ocupe dos gruesos volúmenes que suman más de 900 páginas, sobre todo considerando que se trata de una obra aparentemente breve y "menor" en el corpus de la lírica cancioneril, que apenas ha merecido atención crítica enjundiosa hasta la fecha y que, en verdad, no parecía más que un divertimento literario: un conjunto de versos que nace a manera de juego de cartas para las damas de la corte de Isabel I de Castilla. Y precisamente por estas razones (sus destinatarias femeninas, su función de pasatiempo aristocrático y su condición temáticamente marginal y dispersa) es que la presente publicación constituye una aportación de gran importancia para los estudios filológicos y para los estudios sobre la mujer europea de la Baja Edad Media y del Renacimiento temprano.

Fruto de una labor tenaz a lo largo de más de una década, Roger Boase ha culminado un trabajo de edición y de exégesis encomiables. Esto es así porque ha descifrado las múltiples significaciones de un corpus de poemas del que no 
disponíamos de sus "reglas del juego" y del que ignorábamos las identidades de las nobles que se escondían tras cada una de las 46 cartas (seis miembros de la casa real y cuarenta damas de la corte isabelina). Si tenemos presente que cada carta ofrece dos elementos visuales y dos elementos verbales, a manera de acertijos, que presumiblemente eran cantados, las pistas se encontraban tan sagazmente ocultas que solo un muy atento conocimiento de la cultura y de las dinámicas nobiliarias de la época - en su sentido más generoso- podía arrojar unas luces que, a nuestro juicio, ahora iluminan plenamente el artificioso pasatiempo, muy probablemente compuesto durante el verano de 1496 e incorporado en el Cancionero general de Hernando del Castillo, impreso en 1511.

Boase destaca acertadamente la importancia del Juego trobado como documento literario e histórico, "revealing information, much of it very intimate, about persons and events not to be found in chronicles and other conventional sources, and as a literary document, giving us a personal anthology of songs and courtly verse composed during the previous five decades" (7). Esta circunstancia propicia que el volumen primero se consagre a la edición y, sobre todo, claro está, al análisis de los 46 poemas - en definitiva, un capítulo 2 que ocupa, nada menos, las páginas 17-432 - , mientras que el volumen segundo se consagra a analizar los poemas citados de otros autores, con traducciones versificadas al inglés y comentarios (433627; cap. 3), los versos conocidos como invenciones (628-722; cap. 4), las piezas que adquieren nuevo significado a partir de los nuevos materiales presentados (723-758; cap. 5) y la Carajicomedia (759-785; cap. 6). El conjunto se complementa con unas sustanciosas conclusiones (786-815), a las que siguen diversos índices y repertorios bibliográficos que confirman la envergadura de la empresa culminada.

Dada la extensión impuesta, solo me gustaría destacar en una revista como la presente el interés de Secrets of Pinar's Game para los estudios históricos, artísticos y literarios en torno a la cultura femenina de los siglos XV y XVI: la atención prestada a cada una de las damas de la corte deslinda muy bien su poder y bagaje o trazos de su biografía, como también las lecturas profanas que compartían (por ejemplo, poemas memorizados que debían formar parte de su acervo o el Siervo libre de amor, de Juan Rodríguez del Padrón) en un ambiente en el que perduraban los ideales del amor cortés. Resulta muy pertinente constatar la importancia de una cultura mnemotécnica, muy superior a la derivada de la palabra manuscrita o impresa. También, simultáneamente, un conocimiento compartido de saberes populares y letrados (así, refranes y proverbios o simbolismo de animales, flores y plantas). Por último, quisiera destacar que los análisis e informaciones resultan de gran valor para comprender menos extemporáneamente algunas composiciones de escritoras de la época, entre las que destaca un célebre poema de Florencia Pinar, "D’estas aves su nación" (723-734), que en las últimas dos décadas ha gozado de acechos de toda suerte. 
En definitiva, Roger Boase nos brinda una aportación solvente y poliédrica sobre una composición endiabladamente oscura $-\mathrm{y}$, por ende, malinterpretadaque nos permite calibrar mucho mejor los saberes femeninos (y masculinos) en la esfera cortesana de los reinos hispánicos, los cuales acogen una dilatada tradición previa y que gozarán de clara pervivencia en la cultura literaria del Renacimiento castellano.

\section{"Se conoce que usted es 'Moderna"': Lecturas de la mujer moderna en la colonia hispana de Nueva York (1920-1940)}

María Teresa Vera-Rojas

Madrid y Frankfurt, Iberoamericana-Vervuert, 2018, 390 pp. ISBN: 97884-9192-003-8

La monografía de Vera-Rojas sobre la mujer "moderna" en la colonia hispana de Nueva York a comienzos del xx combina estudios culturales con una marcada perspectiva de género, y posee una temática mucho más contemporánea de lo que por el periodo tratado podría parecer. El título ofrece la clave del contexto de las revistas y diarios (Gráfico, La Prensa, Artes y Letras) analizadas: "Se conoce que usted es 'Moderna'" (es decir, por su aspecto es percibida como mujer moderna) presenta una aparente celebración de la modernidad como deseable para la mujer enmarcada en una economía de consumo. El libro gira así en torno a la formación colectiva a través de la prensa de la mujer hispana como sujeto moderno, objeto de las contradicciones que cohabitan en la modernidad que tradicionalmente se han percibido como representadas con mayor profundidad (utilizando formatos más cercanos a lo trágico) en el sujeto varón, sobre el que pivota la "alta cultura" y el ensayo "serio".

Resulta asombrosa la actualidad en torno, por ejemplo, al concepto entonces naciente de "feminismo", considerado por muchos ya entonces erróneamente como equivalente en negativo del "machismo": muchos de los autores de artículos en estas publicaciones periódicas ven preferible que la mujer hispana sea femenina, no feminista, una dicotomía artificial que aún hoy se resiste a abandonar el debate público. En el libro se explica cómo el feminismo se consideraba una peligrosa influencia "extranjera" (léase norteamericana) que amenazaba valores tradicionales y roles de género profundamente arraigados en la comunidad hispana. 